\title{
APPLICATION OF THE CONCEPT OF CONDICTIO CAUSA DATA CAUSA NON SECUTA IN PECUNIARY SETTLEMENTS BETWEEN COHABITANTS
}

\begin{abstract}
This paper is devoted to the complex and difficult problem of pecuniary settlements between cohabitants or parties in similar relationships. One party often contributes to the partner's property significantly, especially by financing construction of a house on the partner's land or giving him or her money to buy such a house, where they plan to live together. The party makes such patrimonial sacrifices because of the relationship existing between them and with the clear purpose of its continuation. Therefore this financial support can be regarded as a performance rendered in contemplation of continuation of their relationship. However, after several years they split up and the giver seeks restitution of the performance, so the question arises on what ground? Cohabitation is not regulated in Polish law, which is why the courts must search for the proper provisions to solve the dispute. One of the solutions is the application of the concept of performance rendered for an intended purpose that has not been achieved. It can be said that owing to the fact that the relationship is finished the purpose of the performance is subverted. This concept, codified in Article 410 \& 2 of the Polish Civil Code, has roots in Roman law in condictio causa data causa non secuta. It is applied also in foreign legal systems, which enables us to make some comparisons. In this paper several juridical decisions of foreign courts are compared with the famous and controversial judgment of the Polish Supreme Court of $12^{\text {th }}$ January $2006^{1}$ followed by the judgment of Court of Appeal in Poznan of $6^{\text {th }}$ June $2006^{2}$, concerning the claim for restitution filed by a rich Swiss citizen who bought his Polish mistress a flat and two cars, but she left him when she found out that he was married and had adult children. Some basic information on the Roman roots of this condictio is given also.
\end{abstract}

\footnotetext{
Dr. habil., Faculty of Roman Law, Nicolaus Copernicus University, solicitor.

1 II CK 342/05, OSNC [Decisions of the Supreme Court - Civil Chamber] 2006, no. 10, item 113.

2 I ACa 131/2006, unpublished.
} 
Keywords

cohabitants - unjustified enrichment - purpose of the performance - condictio causa data causa non secuta

\section{INTRODUCTION}

In 2006 the Polish Supreme Court issued a controversial judgment concerning settlements between persons who were in an informal relationship ${ }^{3}$. The facts of the case were the following: the plaintiff, a rich citizen of Switzerland, had been in an informal relationship with a Polish woman (without marriage) since 1998. She was twenty four years younger than him and had been previously maintained by her parents. He worked in Poland as a manager in a commercial company and had a wife and adult children who stayed in his home country. During their love affair he maintained her and her daughter and gave her many expensive gifts. Moreover, he bought her two cars and a flat, and financed its furnishings and facilities. They did not live in the same house, but often met, travelled together, and had a sexual relationship. At that time she often declared that she wanted to formalize their relationship, but until 2002 she did not know that he was married and had three adult sons. After she got to know about his family she decided to break up their relationship owing to the fact that he did not spend enough time with her, isolated her from his family and, what was the most important, he refused to divorce his wife. After the breakup he demanded reimbursement of money given for the cars, flat and its facilities. As a legal ground of his claims he invoked unjustified enrichment. She rejected his claims, but confirmed the above mentioned facts. The woman argued that her former partner made all those performances for her benefit with full awareness and in every case it was she who was declared as the owner of the acquired items.

The situation described above is very interesting. It can be said that in a certain sense the facts in this particular case are drastic, but many similar situations take place every day. A couple lives together (unmarried cohabitation) or at least remains in a close personal relationship and one

3 Judgment of 12.01.2006, II CK 342/05, OSNC [Decisions of the Supreme Court - Civil Chamber] 2006, no. 10, item 113. 
partner contributes to another's estate, but after several years they split up. Does the partner have any claim against the counterparty and if so on what grounds? Here one tackles the complex problem of settlements between the parties of an informal relationship, in particular cohabitation. In Polish law there is no legal regulation of unmarried cohabitation or similar relationship, so this difficult problem has to be solved by means of other legal institutions whose primary aim is different; however, they seem to be applicable also in this area. One of the applied solutions is unjustified enrichment, when a party is able to claim that his former partner is enriched at his or her expense.

Similar cases are often recognized by courts in many countries, because this problem can occur and indeed occurs everywhere. Legal systems are very diverse, but they apply similar solutions to some extent. I have done research into the judicial decisions of foreign countries in search of an answer to the question of how cases similar to the Polish one outlined above are solved in those countries. Owing to the limited extent of this paper I chose only the most representative cases. My aim is to compare the motivation of the courts' decisions in those cases in search of similarities and differences. However, at the outset it is useful to make a brief outline of the solutions worked out in Roman law, because this law is the common foundation of the private law of many states, especially in continental Europe.

\section{PERformanCE In CONTEMPLATION OF A FUtURE MARRIAGE THAT DID NOT TAKE PLACE IN ROMAN LAW}

In the sources of Roman law, especially in the Digests of Justinian, one can find many solutions of the greatest Roman jurists in cases which can be compared to the Polish case described above. However, they all refer to performances rendered in contemplation of a future marriage, that means that the performer (solvens) was motivated by the fact that the recipient (accipiens) would get married. In the majority of cases the performance was made by a woman's father (pater familias) with 
the clear intention to make a dowry on account of the expected marriage ${ }^{4}$. It was also possible that the woman herself or a third party, especially her debtor, gave a dowry with that intention ${ }^{5}$. As a rule the object of the performance was acquired in ownership (datio) by a man who was to be the future husband (dotis datio) ${ }^{6}$ however, different possibilities were also admissible ${ }^{7}$. When the marriage in fact was concluded everything went as planned; the problem arose when the expected marriage did not take place.

The recovery of performance rendered as a dowry was recognized already in preclassical law ${ }^{8}$. In order to receive restitution the giver could take advantage of condictio ob rem, known also as condictio ob causam ${ }^{9}$, later named condictio causa data causa non secuta ${ }^{10}$. It was the second condictio in Roman law, after condictio indebiti, in terms of importance. This condictio was used in many different situations where solvens rendered performance in order to achieve an intended purpose $u t$

4 M. Lauria, Matrimonio - dote in diritto romano [Marriage - Dowry in Roman Law], Napoli: L'Arte Tipografica 1952, p. 73 et seq.; C. Sanfilippo, La dote. Corso di diritto romano [Dowry. Course of Roman Law] Catania: Università di Catania 1959, p. 57 et seq.

5 See D.12.4.9pr.; D.12.4.9.1.

6 On dotis datio see: A. Ehrhardt, Iusta causa traditionis. Eine Untersuchung über den Erwerb des Eigentums nach römischem Recht, Berlin-Leipzig: W. de Gruyter \& Company 1930, p. 79 et seq.; M. Lauria, La dote romana [Roman Dowry], Napoli: ITEA 1938, p. 15 et seq.; idem, supra note 4, p. 71 et seq.; H.H. König, Die vor der Ehe bestellte dos nach klassischem römischem Recht, Studia et documenta historiae et iuris 1963, no. 34, passim; Sanfilippo, supra note 4, p. 67 et seq.; J.F. Gardner, Women in Roman Law and Society, Bloomington-Indianapolis: Croom HClb Ltd 1986, p. 100 et seq.; A. Stępkowska, Dos recepticia i dos aestimata w świetle lex Iulia de fundo dotali [Dos Recepticia and Dos Aestimata in the Light of Lex Iulia de Fundo Dotali], Studia Prawnoustrojowe [Legal System Studies] 2007, no. 7, p. 203 et seq.

7 These possibilities were transfer of ownership with the reservation of suspended condition and dotis dictio, which was only a promise to give a dowry.

8 One of the oldest settlements concerning condictio ob rem was taken by the great preclassical jurist Servius Sulpicius Rufus and it referred to a dowry given for a marriage (D.12.4.8).

9 The differences between condictio ob rem and condictio ob causam are unimportant here. On this topic see: F. Schwarz, Die Grundlage der condictio im klassischen römischen Recht, MünsterKöln: Böhlau Verlag 1952, passim; F. Chaudet, Condictio causa data causa non secuta. Critique historique de l'action en enrichissement illégitime de l'art. 62 al 2 CO, Lausanne: Vaudoise 1973, passim; J.D. Harke, Das klassische römische Kondiktionensystem, IURA 2003, no. 54, pp. $49-86$.

10 D.12.4.7.pr.; D.12.4.7.1.; D.22.1.38pr.-1. 
aliquid sequatur ${ }^{11}$, but the purpose was not achieved ${ }^{12}$. Apart from the performance in contemplation of a future marriage the most important instances of the application of that concept ${ }^{13}$ are as follows: performance made in expectation of counter performance on the basis of an agreement which did not constitute a contract enshrined by law (do ut des, do ut facias) ${ }^{14}$, performance rendered to fulfil a condition of an increment (datio propter condicionem) ${ }^{15}$ or on account of a settlement (datio ob transactionem $)^{16}$, donation in contemplation of death (donatio mortis causa) ${ }^{17}$ or sub modo 18 , performance rendered by a slave to receive freedom (datio ob manumissionem $)^{19}$. As a rule the performance was rendered on the basis of a prior agreement, but this kind of agreement did not constitute a contract that entitled a party to claim the performance in court. In other words, at the time when performance was rendered there was no legally binding relation between them; after the performance the situation remained the same ${ }^{20}$, but the giver could reclaim his performance if the recipient did not fulfil his part of the agreement or another intended purpose of the performance did not materialize.

In the case of a dowry the claim for its restitution did not depend on the fact whether a party was responsible for the non materialization

\footnotetext{
11 This very general phrase was used by Quintus Mucius Scaevola (died in 82 BC), the oldest Roman jurist who dealt with datio ob rem, see D.12.6.52. Similar phrases were used by great classical jurists, e.g. ut aliquid fieret (Iulianus, D.12.1.19pr.), ut aliquid facias (Paulus, D.12.6.65.4), ut aliquid optingat (Paulus, D.39.6.35.3).

12 See my detailed analyses of this condictio in: Świadczenie w zamierzonym celu, który nie zostat osiagnięty. Studium z prawa rzymskiego [Performance Rendered for an Intended Purpose That Has Not Been Achieved. Study in Roman Law], Torun: TNOiK 2012, passim.

13 The scope of application of this condictio is described by Paulus in D.12.6.65pr.

14 D.12.4.3.3; D.12.4.5pr.; D.12.4.5.2; D.12.4.16; D.19.4.1.4; D.19.5.5.1; D.19.5.5pr.; D.19.5.5.2 - 5; D.19.5.7.

15 D.12.4.1.1; D.12.4.2; D.12.6.65.3.

16 D.12.4.3pr.; D.12.6.65.1.

17 D.12.1.19pr.; D.39.6.35.2 - 3; D.39.6.37.1; D.39.6.39.

18 D.39.5.2.7; C.4.6.2; C.4.6.3; C.4.6.8.

19 D.12.4.3.2-3; D.12.4.3.7; D.12.4.5.1.

20 With the exception that in late classical law the party to an innominate contract could claim the counter performance by means of actio praescriptis verbis or similar actions, see: M. Artner, Agere praescriptis verbis. Atypische Geschäftsinhalte und klassisches Formularverfahren, Berlin: Duncker \& Humblot 2002, passim; L. Zhang, I contratti innominati nel diritto romano [Innominate Contracts in Roman Law], Milano: Giuffre editore 2007, passim; Sobczyk, supra note 12 , p. 325 et seq.
} 
of the purpose of the performance ${ }^{21}$. A woman or her pater familias could claim the dowry back even if she was to be blamed for the breaking off of the engagement (sponsalia).

The dispute between the Swiss man and his Polish mistress is similar to the cases decided by Roman jurists, but not identical. The most important difference lies in the fact that in the Polish case the parties did not have a common intention to get married; what is more, their relationship cannot be qualified even as unmarried cohabitation. It was rather a relationship of a sexual character. The woman claimed in court that she hoped to marry her partner, but he did not share her expectation owing mostly to the fact that he was already married and did not want to leave his wife. This essential difference does not rule out any comparisons, because he certainly wanted to establish a long-term relationship that still preserved the same character. So when he made all the expenditures for her benefit he acted purposely in expectation of the continuation of their relationship and with the intention of improving the convenience of their meetings.

\section{The POLISH SOLUtion IN THE CASE OF THE DISAPPOINTED LOVER}

In the trial between a Polish woman and her former Swiss lover, he demanded the reimbursement of the cost of a flat, its facilities and two cars on the ground of unjustified enrichment. What was the result of that dispute? The Court of first instance dismissed the claim because the court did not find any grounds that would justify it. In the court's opinion all the money claimed in the lawsuit was only remuneration for her social and sexual services. In appeal against that judgment the plaintiff raised an argument that all those outlays were incurred with the purpose that the couple would create a lasting relationship and after the breakup this purpose was not achieved. He expressly invoked Article $410 \S 2$ of the Polish Civil Code according to which the performance is undue and therefore can be restored - where its intended purpose has not been achieved. In the plaintiff's opinion it does not matter if their connection

21 However this solution was exceptional and was not applied in other cases of datio ob rem, see: Sobczyk, supra note 12, p. 275 et seq. 
was to be classified as cohabitation or any other (looser) relationship. The Court of Appeal in Poznan in the judgment issued on $1^{\text {st }}$ December 2004 dismissed the appeal, because the Court did not find in the facts described above any agreement on the basis of the performance. In the Court's opinion the plaintiff had to prove that the parties had reached agreement (at least per facta concludentia) that in the event that their relationship came to an end the woman would be obliged to return all the items that she had received from him. In fact the plaintiff failed to prove that such an agreement had ever been concluded.

The plaintiff filed a cassation complaint and the Polish Supreme Court set aside the verdict for reconsideration ${ }^{22}$. The Supreme Court assessed the premise of the "intended purpose of the performance" in a completely different way from the Court of second instance. The Supreme Court explained the premises of application of the concept of the performance rendered for "an intended purpose that has not been achieved" (Article 410 \& 2 of the Civil Code). This concept is equivalent to the Roman condictio causa data causa non secuta and the Roman name of this claim is still used in the contemporary Polish doctrine of civil law. According to the Supreme Court this condictio can be applied only in a situation where the person who renders the performance (solvens) and the person who receives it (accipiens) are not bound by any civil law relationship that obliges one party to confer a benefit for the counterparty. Apart from that, in the nature of the civil law relationship governed by this condictio, the party who receives the benefit is not obliged (and previously was not obliged) to render any kind of counter performance. However, the performer's expectation is to receive an equivalent performance to which the recipient is not obliged by law. The essential issue here is "the basis of the performance". In this point the Supreme Court stresses that "the basis of the performance" has to constitute the subject of an agreement between the parties in this sense that the recipient has to know and approve the purpose of the solvens. This agreement is not an element of a legal transaction, but refers to the basis of the performance only. On the other hand, if an agreement constitutes

22 Judgment of the Polish Supreme Court of 12.01.2006, II CK 342/2005, OSNC [Decisions of the Supreme Court - Civil Chamber] 2006, no. 10, item 113. 
an element of legal transaction the provisions on contractual liability instead of unjustified enrichment should be applied. Contrary to the view of the Court of second instance the parties do not have to conclude any agreement concerning the restitution of the performance. Therefore the requirement that the plaintiff has to prove that the defendant promised to return the benefits received was not justified. Finally, the Supreme Court qualified this case as an instance of so called "inducement", that means encouraging the recipient to a behaviour to which she is not or even cannot be obliged by law.

After reconsideration of the case the Court of Appeal in Poznan came to the conclusion that beyond any doubt having bought the flat and its facilities the plaintiff rendered his performance in order to remain with the defendant in the informal partnership. In the Court's opinion the plaintiff strove to obtain from the defendant an equivalent benefit to which she was not legally bound and which consisted in remaining in an informal relationship. The intended purpose of performance was not achieved because she broke up the relationship that linked them. The fact that he bought a flat which was necessary for the duration of their relationship and convenience of their meetings proved that the parties reached agreement on the basis of the performance. For those reasons the preconditions of the application of Article $410 \S 2$ of the Polish Civil Code are met. However, the same consideration does not refer to the cars, because according to the Court they were not bought with the same purpose as the flat, but were simply donated, that is why the claim for restitution of their price was dismissed.

This judgment gave rise to great controversy in the Polish doctrine of civil law.

Tomasz Sokołowski raises many objections to this decision ${ }^{23}$, but here I will mention only the most significant ones. First of all he does not share the opinion of both courts in which they refer to the temporal aspect of achievement of the intended purpose of the performance (however, instead of this achievement this author speaks about the fulfilment of the legal basis of the performance). According to him the period

23 T. Sokołowski, [in:] A. Kidyba (ed.), Kodeks cywilny. Komentarz [Civil Code. Commentary], Warszawa: Wolters Kluwer 2010, note 7 to Article 410. 
of several years within which one has to wait for this fulfilment is too long. The state of uncertainty should be brief, it should last for not longer than several weeks and only exceptionally months. Moreover, in his opinion performance rendered to the cohabitant has a definite character and it is delivered in circumstances in which the performer is fully aware that he does not have an obligation towards his partner, which according to Article $411 \S 1$ of the Polish Civil Code excludes restitution ${ }^{24}$. Apart from that, the long duration of the relationship is in itself a sufficient basis for the performance. In his opinion in this particular case the purpose of the performance was achieved in fact, because the relationship lasted almost four years.

In his gloss to the above mentioned judgment of the Supreme Court Paweł Księżak pays attention to the fact that the parties were not cohabitants, but they were linked only by a loose relationship. In his opinion performance rendered in the framework of cohabitation should be distinguished from gifts given to a lover ${ }^{25}$. This basic distinction leads to the conclusion that in the latter case a married person who gives gifts to his mistress and after the breakup demands that the gifts should be returned acts shamefully. His purpose is immoral and that is why he is not entitled to demand restitution. Moreover, Paweł Księżak does not share the view of the Supreme Court that the purpose of the plaintiff's performance was not achieved. In his opinion in this case the purpose was achieved, because the love affair lasted four years. Because of the immoral purpose of the plaintiff his claim should be dismissed. With the exception of this important peculiarity of the case, that the parties were not cohabitants, but only lovers - which was overlooked by the Supreme Court - Paweł Księżak supports the interpretation of Article 410 § 2 of the Polish Civil Code offered by the Supreme Court ${ }^{26}$.

\footnotetext{
24 P. Mostowik, [in:] System Prawa Prywatnego, t. 6. Zobowiazania. Część Ogólna [System of Private Law, vol. 6. Obligations. General Part], Warszawa: C.H. Beck 2006, p. 238.

25 P. Księżak, Porozumienie stron a zwrot świadczenia - glosa do II CK 342/05 [Agreement Between the Parties and Restitution of Performance - Gloss to II CK 342/05], Monitor Prawniczy [Legal Journal] 2008, no. 10, p. 574 et seq.

26 All those arguments are repeated in: P. Księżak, [in:] K. Osajda (ed.), Kodeks cywilny. Komentarz [Civil Code. Commentary], Warszawa: C.H. Beck 2014, note 90 to Article 410.
} 
The Polish doctrine of civil law accepts the application of the provisions on unjustified enrichment to settlements between cohabitants and similar relationships where the parties do not live together ${ }^{27}$. Apart from unjustified enrichment, the provisions on co-ownership, donation, civil partnership, and contracts are applied in this field ${ }^{28}$. The application of the condictio causa data causa non secuta is also generally approved ${ }^{29}$. This condictio can be used by a cohabitant who financially contributed to the acquisition of land, a house or the construction of a house which became his partner's property, or rendered his services for the benefit of his partner's enterprise ${ }^{30}$.

The Polish Supreme Court has solved disputes between ex-cohabitants on the basis of the provisions of unjustified enrichment several times ${ }^{31}$. In principle, according to the Supreme Court, those provisions can be applied to the settlements between cohabitants ${ }^{32}$. The Courts of Appeal seem to be less favourable to the application of the unjustified enrichment

\footnotetext{
27 A. Szlęzak, Stosunki majątkowe między konkubentami [Property Relations Between Cohabitants], Poznań: Wydawnictwo Naukowe UAM 1992, p. 78 et seq.; M. Nazar, Rozliczenia majątkowe konkubentów [Property Settlements Between Cohabitants], Lublin: Lubelskie Wydawnictwo Prawnicze 1993, p. 93 et seq.; B. Paul, Problemy rozliczeń majątkowych między konkubentami [The Problems of Property Settlements Between Cohabitants], Monitor Prawniczy [Legal Journal] 2002, no. 8, p. 357; Mostowik, supra note 24, p. 236 et seq.; Sokołowski, supra note 23 .

28 Judgments of: the Supreme Court of 22.06.2007, V CSK 114/2007, unpublished, and of 6.12.2007, IV CSK 301/2007, OSNC 2009 [Decisions of the Supreme Court - Civil Chamber], no. 2, item 29; Court of Appeal in Poznań of 12.02.2014, I ACa 1252/2014, unpublished; Court of Appeal in Kraków of 7.03.2013, I ACa 92/2013, unpublished; Court of Appeal in Białystok of 6.06.2013, I ACa 203/2013, unpublished; Court of Appeal in Szczecin of 24.10.2013, I ACa 430/2013, unpublished; Księżak, supra note 26.

29 Księżak, supra note 26; R. Trzaskowski, [in:] G. Bieniek (ed.), Kodeks cywilny. Komentarz. Ksiegga III, Zobowiązania [Civil Code, Commentary, Book 3, Obligations], Warszawa: LexisNexis 2014, note 22 to Article 410; G. Karaszewski, [in:] J. Ciszewski (ed.), Kodeks cywilny. Komenarz [Civil Code. Commentary], Warszawa: LexisNexis 2013, note 6 to Article 410, J. Łukasiewicz, Pytanie o zasadność causa wspólnoty życiowej przy czynnościach przysparzających pomiędzy konkubentami [A Question Concerning the Causa of a Life Community in Legal Incremental Acts Between Cohabitees], Studia Prawnicze [Legal Papers] 2013, vol. 1, p. 128 et seq.

30 Księżak, supra note 26.

31 Judgments of the Supreme Court of 26.06.1976, III CRN 132/74, unpublished, and of 16.05.2000, IV CKN 32/2000, OSNC [Decisions of the Supreme Court - Civil Chamber] 2002, no. 12, item 222.

32 Judgment of the Supreme Court of 16.05.2000, IV CKN 32/2000, OSNC [Decisions of the Supreme Court - Civil Chamber] 2002, no. 12, item 222.
} 
law in this field. According to the Court of Appeal in Warsaw unjustified enrichment cannot be a universal ground or pecuniary settlements after the end of the informal (unmarried) relationship; however, such a ground cannot be rejected generally ${ }^{33}$. The Court of Appeal in Białystok accepts this ground of claims, but only as a last resort, in situations where other provisions are inapplicable ${ }^{34}$. However, in practice the Court of Appeal in Warsaw applied condictio causa data causa non secuta to settlements between cohabitants ${ }^{35}$. A similar view was approved by the Court of Appeal in Szczecin ${ }^{36}$, Poznań ${ }^{37}$ and in Wrocław ${ }^{38}$. Nevertheless, the courts are reluctant to apply this condictio, therefore in the first place they seek other provisions which better fit particular circumstances of the dispute between ex-cohabitants.

\section{SCOTTISH CASE SHILLIDAY V. SMITH}

Courts in Scotland apply in this kind of litigations the concept of condictio causa data causa non secuta and often emphasize that it has roots in Roman law. It is important to mention that the Scots system of private law belongs to the so called mixed systems, so it contains elements both of continental law and of common law. In this particular area this system takes patterns of continental unjustified enrichment law. Roman law had a great impact on the development of private law in Scotland 39 . The influence of Roman law is particularly noticeable in the unjustified enrichment law ${ }^{40}$.

\footnotetext{
33 Judgment of the Court of Appeal in Warsaw of 26.04.2011, I ACa 1049/10, unpublished.

34 Judgment of the Court of Appeal in Białystok of 6.02.2014, I ACa 714/2013, unpublished; compare with the judgment of the Supreme Court of 30.01.1986, III CZP 79/85, OSNCP [Decisions of the Supreme Court - Civil and Work Chamber] 1987, no. 1, item 2.

35 Judgment of the Court of Appeal in Warsaw of 4.02.2014, I ACa 719/13, unpublished.

36 Judgment of the Court of Appeal in Szczecin of 25.03.2014, I ACa 755/13, unpublished.

37 Judgment of the Court of Appeal in Poznań of 25.06.2014, I ACa 360/14, unpublished.

38 Judgment of the Court of Appeal in Wrocław of 19.11.2013, I ACa 1131/13, unpublished.

39 Details see: W. Gordon, Roman law in Scotland, [in:] R. Evans-Johnes (ed.), The Civil Law Tradition in Scotland, Edinburgh: The Stair Society 1995, pp. 13-40.

40 WDH Sellar, Unjust Enrichment, [in:] R. Black, H. Henderson, J.M. Thomson, K. Miller (eds), The Laws of Scotland: Stair Memorial Encyclopaedia, Edinburgh: Butterworths 1988, vol. 15, pp. 11-65; H. MacQueen, Unjust Enrichment in Scots Law, [in:] Eltjo J.H. Schrage (ed.) Unjust Enrichment. The Comparative Legal History of the Law of Restitution, Berlin: Duncker \& Humblot 1995; H.L. MacQueen, Payment of Another's Debt, [in:]
} 
In the case Shilliday $v$. Smith recognized by the Court of Session ${ }^{41}$ the parties lived together, planned to get married, and even became engaged. The defendant bought a house which needed repairs. Some costs of the repairs, materials and equipment of the house were covered by the plaintiff. After two years their relationship deteriorated to the extent that when the building works to the house were almost complete, the defendant locked the plaintiff out. The plaintiff sued her former partner claiming that the payments had been made in contemplation of marriage and that condition failed to materialize. In deciding this case the Court of Session relied on the concept of condictio causa data causa non secuta. Lord President Rodger stressed the general provision that "a person may be said to be unjustly enriched at another's expense when he has obtained a benefit from the other's acting or expenditure, without there being a legal ground which would justify him in retaining that benefit". In his opinion situations where a person is unjustly enriched at another's expense correspond, if only somehow loosely, to situations where remedies were granted in Roman law, therefore in referring to the relevant categories Scots law tends to use the terminology of Roman law. The term condictio causa data causa non secuta covers situations where A is enriched because B has paid him money or transferred property to him in the expectation of receiving a consideration from $\mathrm{A}$, but $\mathrm{A}$ does not provide that consideration. The relevant situations in this group also include cases where $B$ paid the money or transferred the property to A in contemplation of a marriage which does not take place. That is why - according to the final decision of the Court - the plaintiff is entitled to recover her payments which she made for the house.

Resolutions for similar cases in Scotland are usually based on the principle set by Stair in his Institutions of the law of Scotland written in the 17th century42: "[t]he duty of restitution extendeth to those things, quae cadunt in non causam, which coming warrantably to our hands

R. Zimmermann, D. Johnston (eds), Unjustified Enrichment: Key Issues in Comparative Perspective, Cambridge: Cambridge University Press 2002, pp. 458-489.

411998 S.C. 725, 1998 SLT 976.

42 James Dalrymple, $1^{\text {st }}$ Viscount of Stair, Institutions of the Law of Scotland Deduced from its Originals, and Collocated with the Civil, Canon, and Feudal Laws and with the Customs of Neighbouring Nations, first published in 1681, passage I.7.7. 
and without any paction of restitution, yet if the cause cease by which they become ours, there superveneth the obligation of restitution of them. Whence are the condictions in law, sine causa and causa data causa non secuta, which have this natural ground; and of which there are innumerable instances. As all things that become in the possession of either party in contemplation of marriage, the marriage (which is the cause) failing to be accomplished, the interest of either party ceaseth, and either must restore".

In the quoted passage Stair refers to and draws a parallel with Roman law ${ }^{43}$. The passage concerns two situations. The first (described by Stair as "sine causa") is where property comes into someone's hands on a particular basis which then ceases to exist. The second (described as "causa data causa non secuta") is where property comes into the person's hands on the basis of some future event which fails to materialize. In either case the property must be restored. The important thing to notice is that in both cases the duty to restore is said to be based not on agreement (pactum), but on a natural ground; it is a duty imposed by law. The basis of liability to reverse unjust enrichment is not contractual, but rests on this separate duty imposed by law. Owing to this fact there was no need for the pursuer to point to any kind of contract between the parties under which the pursuer paid the various sums on condition that they married. Nor need the pursuer prove that her expenditure was conditional in any technical sense. The remedies sought by the pursuer are not dependent on the existence of any agreement between her and the defender.

\section{THE BROKEN LEBENSGEMEINSCHAFT IN AUSTRIA}

In an Austrian case adjudicated by the Supreme Court of Justice (Der Oberste Gerichtshof) on $28^{\text {th }}$ January $1986^{44}$ the parties lived together in a partnership (Lebensgemeinschaft) for three years. The pursuer transferred a large amount of money to the defendant's account to let him

43 Compare: W.D.H. Sellar, Shilliday v. Smith: Unjust Enrichment Through the Looking Glass, Edinburgh Law Review 2001, vol. 5, p. 80.

44 OGH 1Ob504/86, available at: www.ris.bka.gv.at [last accessed: 22.12.2014]. 
overcome his financial difficulties. The court of first instance assessed that the relationship between the parties at that time resembled a wellfunctioning marriage. The pursuer could not imagine any future without the defendant and she was ready to make every sacrifice for him. She transferred money to him in contemplation of a common future and common acquisitions. The ground for her financial performance was the continued existence of their partnership. After the breakup this ground became subverted.

This dispute was adjudicated on the basis of Article 1435 of the Austrian Civil Code (ABGB), which expresses the concept of condictio causa data causa non secuta. On that basis the Court holds that it is possible to raise an unjustified enrichment claim in a situation where somebody makes performance for the benefit of another person without any contractual basis, but in expectation of a future result which fails to materialize. It is enough that the purpose of the performance, that means the expected result, can be recognized by the recipient. It does not have to be agreed expressly. This principle is applicable also where the performance was made in expectation of the continuation of the partnership between the giver and recipient. The pursuer does not have to prove the existence of any contractual basis of her performance, because such a basis is not necessary. However, there is an important difference between a marriage and a partnership, namely in the partnership the expectation of the continued being together is not obvious, so this expectation cannot be only unilaterally reserved by the performer or cannot be unrecognizable by the recipient. The burden of proof in this respect rests on the plaintiff.

The judgment in the case described above is not unique or exceptional. According to many judicial decisions of the Austrian Supreme Court in a situation where somebody who lives in cohabitation renders performance for his partner's benefit, and especially contributes to the construction of a house where they live together, the purpose of the performance is subverted after the end of their relationship ${ }^{45}$. Owing to this fact he is entitled to claim restitution of his performance

45 Judgment of 31.01.1980, OGH 7Ob802/79, SZ 53/20, available at: www.ris.bka.gv.at [last accessed: 22.12.2014] with the earlier judgments mentioned in this verdict. 
on the ground of the non-materialization of the expected result (condictio causa data causa non secuta) laid down in $\S 1435$ ABGB. The success of the restitution claim does not depend on the existence of any contract between the parties; the claim is admissible without any contract ${ }^{46}$. An unjustified enrichment claim is therefore granted if the performance was provided in the recognizable expectation of the continued existence of the cohabitation. Not the motive of the performer itself, but the fact that this motive and the reason for performance are objectively recognizable for the recipient is decisive ${ }^{47}$. However, the performance which is not rendered with such a long-term purpose, but merely to cover the costs of everyday life, cannot be the subject of restitution. This kind of performance is limited in time by its nature, which is why it cannot be said that its purpose is subverted after the breakup. In conclusion, only exceptional performance rendered in the recognizable expectation of the continuation of the cohabitation can be reclaimed ${ }^{48}$. In this category one may include acquisition of land and construction of house.

\section{SWISS CASE OF A SHOP SOLD TO A WOULD-BE SON-IN-LAW AT A VERY REDUCED PRICE}

This case from $1956^{49}$ is even more complex than the ones described above and is a little different, because it resembles more the Roman dowry than disputes between former cohabitants. However, the applied solution still remains the same and the detailed considerations of the court may be useful also in cases between cohabitants. A father acting in the belief that his daughter will get married sells his shop to her fiancé at a very reduced price. The fiancé invests much money in renovation of the shop in good faith that he will marry that woman; however, the marriage does not take place. After the death of the father his heirs demand that

\footnotetext{
46 See the judgment described in the footnote above with earlier judgments and literature mentioned therein.

47 Judgment of 25.02.1988, OGH 6Ob725/87, available at: www.ris.bka.gv.at [last accessed: 22.12.2014].

48 Judgment of 30.11.1987, OGH 4Ob610/87, available at: www.ris.bka.gv.at [last accessed: 22.12.2014].

49 Judgment of 9.10.1956, BGE 82 II 430, available at: www.bger.ch [last accessed: 22.12.2014].
} 
the buyer of the shop at a special price should pay them the difference between this special price and the market value of the shop. As the basis of their claim they indicate unjustified enrichment - Article 62 of the Swiss Code of Obligation. In their opinion their father decided to sell the shop at a reduced price only because the buyer was engaged to his daughter and this reduction was made only in expectation of the future marriage.

One important difference between this case and the cases described above is the existence of a contract of sale concluded by the father and his daughter's fiancé, so at first glance this case has nothing to do with unjustified enrichment. On the surface this dispute belongs to the law of contracts because the transfer of assets undeniably had contractual ground. In fact this impression is misleading because of the considerable reduction of the price which was caused by the particular unusual circumstances of the sale.

The Swiss Supreme Court (Das Bundesgericht) based its decision on Article 62 of the Swiss Code of Obligation. A person is obliged to return the unjustified enrichment in a situation where he receives a perfomance on a basis that fails to materialize (condictio causa data causa non secuta). It does not require any agreement between the parties on the ground on which one party incurs an obligation to render performance to the other. It is also possible that a person receives a performance which in part relies on the contractual basis (especially in return for his own performance) and in part constitutes unjustifiably acquired benefit. In such a situation there is a mixed contract, mixed in this sense that the payable perfomance is mixed with the gratuitous one. It is not relevant that the payable part of the performance has the same legal ground as the gratuitous one. When the basis of the gratuitous part of the performance does not materialize the perfomer is entitled to claim this part back.

In this context the Supreme Court paid attention to the intention of the performer. The contract was concluded in circumstances in which both parties were convinced that the buyer would marry the seller's daughter, to whom he was engaged. For the seller this fact was of crucial importance and deeply affected his will. His intention was recognized by the buyer, which was confirmed by the notary who prepared the contract. The planned marriage - not the engagement itself - was the ground for the gratuitous part of the performance; if this ground 
is not materialized, this part should be given back. It is not required that the parties should expressly agree the extent in which the performance has a gratuitous character. It is enough that in the given circumstances the recipient is aware of the mixed character of the contract. Moreover, the parties do not have to make any reservation in the contract that any part of the performance will be returned if the engagement ends without marriage, because the claim for unjustified enrichment is specified by law, regardless of the contract's provisions. Apart from that, the recipient cannot invoke the fact that he lost the enrichment before the litigation, because from the time the contract was entered into he should have been aware of his potential obligation to restore the enrichment if he did not enter into marriage with the performer's daughter.

The Court ruled that an unjustified enrichment claim could refer only to that part of the performance which was gratuitous. It does not mean necessarily that its value should be estimated as the difference between the market value of the whole performance and the counter performance (in this case the price paid by the would-be son-in-law). When it is possible to infer, at least from the circumstances, how the parties evaluated the gratuitous part of the performance, only this subjective valuation should be restored, even if it is less than the above mentioned difference. It is important also that after the restitution the bona fide recipient should not be left in a worse condition than he would have been in without this contract. In this case the recipient acted in good faith because at the time of the conclusion of the contract he planned to marry the contractor's daughter. Being convinced that the marriage would take place and his acquisition would become definitive soon he decided to make expensive improvements to the acquired shop.

\section{CONCLUSIONS}

All the cases described in this paper deal with the same problem in spite of many differences in details which result from the particular circumstances of each case. This common general problem concerns settlements between former partners in situations where one of them contributed to another's property and after the end of their relationship seeks restitution. The common solution to that problem is the application 
of condictio causa data causa non secuta, a remedy created by Roman jurists which still preserves its Roman foundations. The similarity of the concepts used by the courts let one draw some conclusions which can be helpful in deciding similar cases, regardless of the country where they take place. The first final conclusion is trivial, but very important: the concept of causa data causa non secuta is applicable, which is why there is no need to search for other provisions which can constitute the basis of the court's decision. The applicability of that condition is not obvious, especially in those countries where unjustified enrichment claims are regarded as only subsidiary, so the courts prefer other legal grounds, and resort to unjustified enrichment only if there is no alternative solution. The fact that courts in other states do not hesitate to take advantage of that condictio is an argument for its general application.

The detailed problems dealt with in the court's decisions are the same to a considerable extent. One of them refers to the existence of potential agreement between the cohabitants which can serve as a basis and justification of the performance. As a rule a certain kind of agreement is required; however, this agreement cannot have a contractual character, because otherwise the contract law instead of unjustified enrichment is applied. The kind of agreement which is necessary and sufficient here is described as the "legal basis of the performance". One party confers a benefit on another to achieve a purpose which is at least recognizable for the recipient and approved by him at least per facta conludentia. This purpose usually refers to the further continuation of their relationship; especially if one party contributes to the construction of a home on the partner's land, he usually does it in expectation that they will live together there. It is enough that the purpose is recognizable and accepted by the recipient, which is why it should be something more than a mere motive of the giver. On the other hand, the purpose does not have to be the subject of an agreement of a contractual character; in particular, the parties do not have to agree that the performance will be returned if their relationship comes to an end. If they agree, the restitution of performance contract law seems to be preferable.

Another important issue is the subject of the performance. Without doubt it must be something much more than the usual contribution to the maintenance of a common household, e.g. buying food, paying 
bills, buying articles of daily use or generally covering the costs of everyday life. Condictio is applied rather in exceptional cases where the amount of the contribution to the partner's property is significant and constitutes a valuable and lasting benefit. 
